\title{
酸性硫酸业鉛および硫酸銅溶液の 表面張力に及ぼすゼラチン添加の影響*
}

\author{
蘇 慶 泉 ${ }^{1}$ 梅 津 良 昭 ${ }^{2}$ 户 沢 一 光 ${ }^{3}$
}

[UDC 669. 347/537]

\section{The Effect of Addition of Gelatin on Surface Tension of Acidic Zinc Sulfate and Copper Sulfate Solutions}

by Qing-quan $\mathrm{SU}^{1}$, Yoshiaki UMETSU ${ }^{2}$ and Kazuteru TOZAWA ${ }^{3}$

Surface tension was determined for acidic zinc sulfate and copper sulfate solutions with the compositions corresponding to those of electrolyte solutions generally used in electrolytic production of zinc and copper. The solution composition was as follows:

Acidic zinc sulfate solutions,

$\mathrm{H}_{2} \mathrm{SO}_{4}(\mathrm{~g} / l), 150$ and $200 ; \mathrm{ZnSO}_{4}(\mathrm{~g} / \mathrm{Zn}), 0-80 ; \mathrm{MgSO}_{4}(\mathrm{~g} / \mathrm{l} \mathrm{Mg}), 0-20$.

Acidic copper sulfate solutions,

$\mathrm{H}_{2} \mathrm{SO}_{4}(\mathrm{~g} / \mathrm{l}), 50,150$ and $200 ; \mathrm{CuSO}_{4}(\mathrm{~g} / \mathrm{l} \mathrm{Cu}), 0-70 ; \mathrm{NiSO}_{4}(\mathrm{~g} / l \mathrm{Ni}), 0-20$.

The temperature range was 25 to $60^{\circ} \mathrm{C}$.

The following expression fits all the observed values of surface tension with a standard deviation of 0.17 $\mathrm{dyn} / \mathrm{cm}$.

$\gamma(\mathrm{dyn} / \mathrm{cm})=75.30-0.153 t+0.007\left(\left[\mathrm{H}_{2} \mathrm{SO}_{4}\right]+[\mathrm{M}]\right) t+0.67\left[\mathrm{H}_{2} \mathrm{SO}_{4}\right]+2.12[\mathrm{M}]$

where $t$ is temperature in ${ }^{\circ} \mathrm{C}$ and $[\mathrm{M}]$ is the total concentration in $\mathrm{mol} / \mathrm{l}$ of the metal ions considered in this work,

$$
[\mathrm{M}]=[\mathrm{Zn}]+[\mathrm{Mg}]+[\mathrm{Cu}]+[\mathrm{Ni}]
$$

The effect of addition of gelatin on the surface tension of the acidic sulfate solutions was also investigated at the gelatin concentrations up to $200 \mathrm{mg} / l$. The surface tension markedly decreases with an increase in the gelatin concentration. However, the surface tension increases gradually with time after the addition of gelatin toward the values for the solutions without added gelatin. This rise in surface tension is more pronounced at higher acid concentration and at higher temperature and can be attributed to the progress of hydrolysis of gelatin in the acidic sulfate solutions.

Thiourea added in the acidic sulfate solutions was found to have no detectable effect on the surface tension of the solutions with and/or without gelatin added.

$\left(\begin{array}{lll}\begin{array}{l}\text { 1 } \\ \text { 1. Graduate Student }\end{array} & \text { 2. Assoc. Prof., Dr. } & \text { 3. Prof., Dr. }\end{array}\right)$

\section{1. 緒言}

著者らは，亜鉛あるいは銅の電解の実操業で用いられる電解液 の組成, 温度を中心とした広い範囲にわたって酸性硫酸塩溶液の 密度および粘性 $^{1) 2)}$, 電気伝導度 ${ }^{3) 4)}$ を測定し,これら諸量を硫酸, $\mathrm{CuSO}_{4}$ あるいは $\mathrm{ZnSO}_{4}$, 実操業電解液中に含まれる代表的な共 存塩の濃度および温度の関数として整理してきた。この研究の一 環として, 気泡の発生, ぬれ, ミストの発生などに関する検討に

* 1989 年 3 月 18 日受付 7 月 24 日受理 昭和 63 年度日本鉱業会 春季大会において一部発表

1. 正会員 東北大学大学院

2. 正会員 工博 東北大学助教授 選鉱製錬研究所

3. 正会員 工博 東北大学教授 選鉱製錬研究所
必要な溶液の表面張力の測定を行なった。とくに, 電解液への代 表的な有機添加剤である膠が最も敏感に影響を及ぼす溶液の物理 的性質として表面張力を取り上げ，ゼラチン(精製した膠)の添 加が溶液の表面張力に及ぼす影響を調べた。

膠は古くから良好な電析状態の維持を目的として電解液へ添加 されている。また, 亜鉛の電解採取では膠の添加によって電析亜 鉛の結晶形状が変わるとともに, 適量の添加は電解夜中の微量の $\mathrm{Sb}, \mathrm{Ge}, \mathrm{As}$ 等による電流効率の低下を抑制する効果があるとの 報告がみられる ${ }^{5)}$ 。

高分子の誘導タンパク質であるゼラチンは, 高い酸濃度の溶液 中で煮沸すると分解し, 分子量の小さいタンパク質, アミノ酸へ と変化していくことが知られているが, 電解条件こ相当する環境 下での変化については不明な点が多い。また, 電解の操業では電 
析状態の劣化が観察される毎に膠を添加し，電析状態の回復を図 るという方策が講じられている。

本報では, $\mathrm{MgSO}_{4}$ を含む酸性 $\mathrm{ZnSO}_{4}$ 溶液および $\mathrm{NiSO}_{4}$ を含む 酸性 $\mathrm{CuSO}_{4}$ 溶液の表面張力を硫酸, 各金属イオンの分析濃度およ び温度の関数として表した結果と, 電解液に近い組成, 温度の酸 性硫酸塩溶液にゼラチンを加えた場合の表面張力の降下および表 面張力の経時変化について報告する。

\section{2. 実験方 法}

試料溶液の調製には市販特級試薬の $\mathrm{Cu} \mathrm{SO}_{4} \cdot 5 \mathrm{H}_{2} \mathrm{O}, \mathrm{ZnSO}_{4}$. $7 \mathrm{H}_{2} \mathrm{O}, \mathrm{Ni} \mathrm{SO}_{4} \cdot 6 \mathrm{H}_{2} \mathrm{O}, \mathrm{MgSO}_{4} \cdot 7 \mathrm{H}_{2} \mathrm{O}$ および精密分析用硫酸 を使用した。ゼラチンは市販の試薬 (Janssen Pharmaceutica)を それ以上の精製を行なわずに用いた。

試料溶液は亜鉛および銅の電解操業で採用されている電解液の 組成を中心とした硫酸および硫酸塩濃度で調製した。

酸性 $\mathrm{ZnSO}_{4}$ 溶液は, $\mathrm{H}_{2} \mathrm{SO}_{4}$ 濃度 $150 \mathrm{~g} / l$ を中心とし, $\mathrm{ZnSO}_{4}$ 濃 度を0 $80 \mathrm{~g} / l \mathrm{Zn}$ で变化させた。亜鉛電解採取電解液中の代表 的な共存硫酸塩である $\mathrm{MgSO}_{4}$ が表面張力に及ぼす影響を $20 \mathrm{~g} / l$ $\mathrm{Mg}$ までの範囲で調べた。一方, 酸性 $\mathrm{CuSO}_{4}$ 溶液は電解採取およ び電解精製の電解液の $\mathrm{H}_{2} \mathrm{~S} \mathrm{O}_{4}$ 濃度を考虑して, $\mathrm{H}_{2} \mathrm{SO}_{4}$ 濃度を 50 , 150 および $200 \mathrm{~g} / l$ とし, $\mathrm{CuSO}_{4}$ 濃度を $0 \sim 70 \mathrm{~g} / l \mathrm{Cu}$ とした。銅の 電解精製電解夜中に多くみられる共存硫酸塩として $\mathrm{NiSO}_{4}$ をとり あげ, $20 \mathrm{~g} / l \mathrm{Ni}$ までの範囲で表面張力に対する影響を調べた。

表面張力の測定は, 最大泡圧法によって行なった。内径 $0.01 \mathrm{~cm}$ 申のガラス製毛細管をノズルとして使用し, 脱泡間隔が一定にな るようにガスリザーバーから窒素ガスをノズルに送り気泡を発生 させ, マノメータによって最大泡圧を測定した。毛細管の径は顕 微鏡による読み取りで測定し, さらに各温度で純水を用いて装置 の検定を行なった。温度 $t\left({ }^{\circ} \mathrm{C}\right)$ における純水の表面張力 $\gamma(\mathrm{dyn})$ $\mathrm{cm})$ は

$$
\gamma=75.680-0.138 t-3.56 \times 10^{-4} t^{2}+4.7 \times 10^{-7} t^{3}
$$

により ${ }^{6)}$ 計算した值を採用した。

本実験では気泡発生用ガスとして窒素ガス( 99.9995\%) を用いた が，代表的な組成の溶液においてガスの精製（脱酸素）の有無に よる測定値への影響はみられなかった。したがって, 測定では窒 素ガスをそれ以上の精製を行なわずに使用した。また, 窒素がス シールによって試料溶液が測定中に空気と接触しないようにした。 膠が表面張力に及ぼす影響は, 垔鉛電解採取電解液を代表する $\mathrm{H}_{2} \mathrm{SO}_{4} 150 \mathrm{~g} / l, \mathrm{Zn} 60 \mathrm{~g} / l$ および銅の電解精製電解液の代表値 として $\mathrm{H}_{2} \mathrm{SO}_{4} 200 \mathrm{~g} / l, \mathrm{Cu} 40 \mathrm{~g} / l$ の組成を中心とする溶液に精

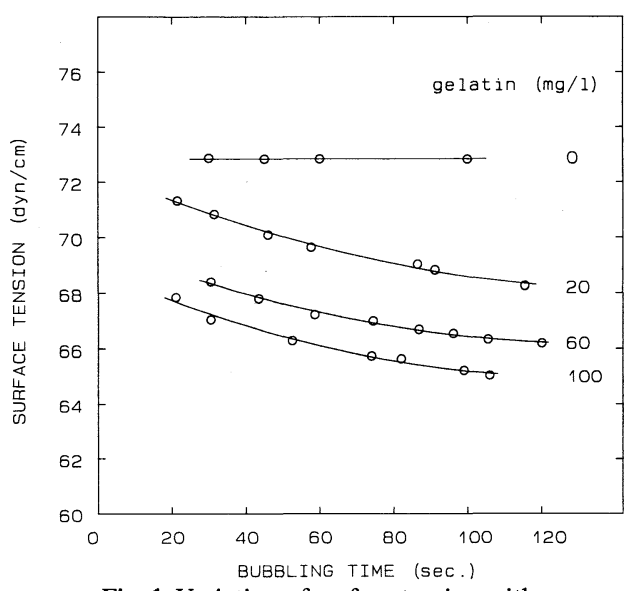

Fig. 1 Variation of surface tension with bubbling time.

$\mathrm{H}_{2} \mathrm{SO}_{4} 150 \mathrm{~g} / \mathrm{l} ; \mathrm{Zn} 60 \mathrm{~g} / l ; 40^{\circ} \mathrm{C}$
製膠であるゼラチンを添加して測定した。

ゼラチンの添加による表面張力の変化を調べる測定では, 所要 量のゼラチンを含む各組成の試料液を各温度における測定直前に 調製した。また，ゼラチンを含む溶液を測定温度に保持し，ゼラ チン添加後の所要時間毎に表面張力を測定し, 表面張力の経時変 化を追跡した。

試料溶液は恒温水槽を用い, 各測定温度で土 $0.2{ }^{\circ} \mathrm{C}$ で一定に保 った。

ゼラチンを添加した溶液では測定值が脱泡間隔に伴って变化し た。図 1 に最大泡圧から求めた表面張力の值と脱泡間隔の関係の 一例を示した。ここでは, $\mathrm{H}_{2} \mathrm{SO}_{4} 150 \mathrm{~g} / l, \mathrm{Zn} 60 \mathrm{~g} / l$ の溶液に対 し, ゼラチン無添加および $20,60,100 \mathrm{mg} / l$ 添加の場合を例示し た。ゼラチン無添加の場合は脱泡間隔によらず一定の表面張力の 值が得られるが，ゼラチンを含む溶液では脱泡間隔が長くなるに したがって表面張力の測定値が低下し, $100 \mathrm{sec}$ 以上ではその変化 が小さくなった。この脱泡間隔に伴う表面張力の変化は, 後述の 界面へのゼラチンの正吸着が飽和状態に達するまでに時間を要す るためであると考えられる。一方，マノメータにおける最大泡圧 の読み取り精度は脱泡間隔が $100 \mathrm{sec}$ を超えて長くなるにしたが って悪くなる。ほかの組成およびゼラチン濃度の溶液でも同様な 結果が得られたので, ゼラチンを含む溶液に対しては脱泡間隔 $100 \mathrm{sec}$ での測定値を表面張力の值として採用した。なお，最大 泡圧の測定に要する時間は，表面張力の経時変化が進行する時間 に比較して十分に短いものと判断された。

\section{3. 結果および考察}

\section{$3 \cdot 1$ 酸性硫酸塩溶液の表面張力}

本報告では実操業データとの対比を容易にするために硫酸, 硫 酸塩の濃度をそれぞれ $\mathrm{H}_{2} \mathrm{SO}_{4}$ および各金属イオンの分析值 $(\mathrm{g} / l$ あるいは $\mathrm{mol} / l)$ で示し, 表面張力は $\mathrm{dyn} / \mathrm{cm}\left(1 \mathrm{dyn} / \mathrm{cm}=10^{-3}\right.$ $\mathrm{N} / \mathrm{m}$ )を用いて表した。

$3 \cdot 1 \cdot 1$ 表面張力の溶夜組成に伴う变化 図 2 に $\mathrm{H}_{2} \mathrm{SO}_{4}$ $150 \mathrm{~g} / l$ の一連の酸性 $\mathrm{ZnSO}_{4}$ 溶液における表面張力の $\mathrm{ZnSO}_{4}$ 濃 度に伴う変化を示した。 $\mathrm{H}_{2} \mathrm{SO}_{4}$ 濃度が一定の溶液では表面張力は $\mathrm{ZnSO}_{4}$ 濃度の上昇に伴ってほぼ直線的に増加した。 $25 \sim 60^{\circ} \mathrm{C}$ の 各温度で同様な傾向がみられ, $\mathrm{ZnSO}_{4}$ 濃度に伴う表面張力の増加 の度合は温度によって強い影響をうけず，いずれの温度において もほぼ同程度であることがわかる。

亜鉛電解液中には $\mathrm{Mg} \mathrm{SO}_{4}$ が比較的高い濃度で含まれている場 合が多い。 $\mathrm{MgSO}_{4}$ を $20 \mathrm{~g} / l \mathrm{Mg}$ までの範囲で含む $\mathrm{H}_{2} \mathrm{SO}_{4}$ 濃度

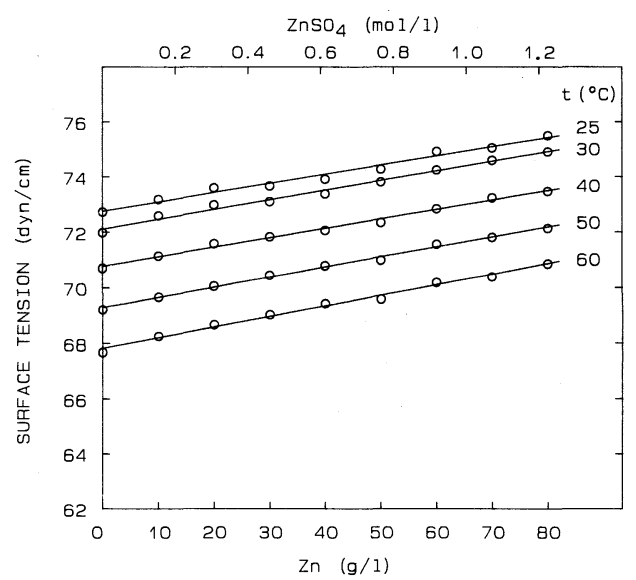

Fig. 2 Variation of surface tension with concentration of $\mathrm{ZnSO}_{4}$. $\mathrm{H}_{2} \mathrm{SO}_{4} 150 \mathrm{~g} / \mathrm{l}$ 


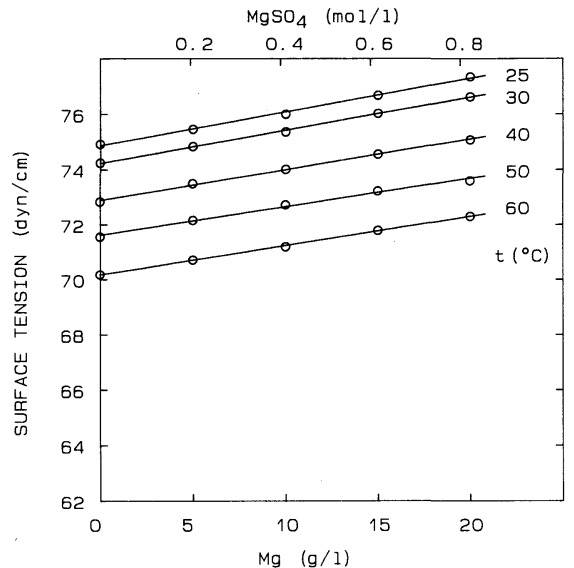

Fig. 3 Variation of surface tension with concentration of $\mathrm{MgSO}_{4}$ $\mathrm{H}_{2} \mathrm{SO}_{4} 150 \mathrm{~g} / l ; \mathrm{Zn} 60 \mathrm{~g} / l$

$150 \mathrm{~g} / l, \mathrm{Zn} 60 \mathrm{~g} / l$ の溶液の表面張力を図3に示した。前述の $\mathrm{ZnSO}_{4}$ 濃度に伴う表面張力の変化と同様に, $\mathrm{MgSO}_{4}$ 濃度の上昇 に伴って溶液の表面張力がほぼ直線的に增大していることがみら れる。また, 表面張力の $\mathrm{Mg} \mathrm{SO}_{4}$ 濃度依存性は温度によって大きな 影響を受けなかった。

酸性 $\mathrm{CuSO}_{4}$ 溶液の表面張力の溶液組成に伴亏変化を図 4〜6 に示した。ここでは，銅の電解採取および電解精製の電解液を代 表する $\mathrm{H}_{2} \mathrm{SO}_{4}$ 濃度としてそれぞれ $50 \mathrm{~g} / l$ および $200 \mathrm{~g} / l$ を考えた。 $50 \mathrm{~g} / l \mathrm{H}_{2} \mathrm{SO}_{4}$ と低い $\mathrm{H}_{2} \mathrm{SO}_{4}$ 濃度における表面張力の $\mathrm{CuSO}_{4}$ 濃
度に伴う変化を図 4 に示した。図 5 は $\mathrm{H}_{2} \mathrm{SO}_{4}$ 濃度 $200 \mathrm{~g} / l$ の溶液 に対する表面張力の測定結果である。いずれの $\mathrm{H}_{2} \mathrm{SO}_{4}$ 濃度におい ても, 表面張力は $\mathrm{CuSO}_{4}$ 濃度の上昇とともに直線的に増加し， $\mathrm{CuSO}_{4}$ 濃度に伴う変化の度合は $\mathrm{H}_{2} \mathrm{SO}_{4}$ 濃度によってほとんど影 響を受けなかった。酸性 $\mathrm{Cu} \mathrm{SO}_{4}$ 溶液の表面張力の $\mathrm{H}_{2} \mathrm{SO}_{4}$ 濃度に 伴う変化を図 6 に示した。ここでは, $50 \mathrm{~g} / l \mathrm{Cu}$ の溶液と $\mathrm{Cu} \mathrm{SO}_{4}$ を含まない $\mathrm{H}_{2} \mathrm{SO}_{4}$ 溶液の表面張力を比較した。いずれの場合も $\mathrm{H}_{2} \mathrm{SO}_{4}$ 濃度とともに表面張力がほぼ直線的に上昇し, $\mathrm{H}_{2} \mathrm{SO}_{4}$ 濃 度に伴う变化の度合は $\mathrm{CuSO}_{4}$ 濃度によって大きな影響を受けな かった。

$\mathrm{H}_{2} \mathrm{SO}_{4}$ 濃度 $150 \mathrm{~g} / l$ の溶液に対して $\mathrm{ZnSO}_{4}, \mathrm{CuSO}_{4}, \mathrm{MgSO}_{4}$ の賑度に伴う表面張力の变化を比較した結果を図 7 に示す。

$\mathrm{H}_{2} \mathrm{SO}_{4}$ 濃度に伴う表面張力の変化は基準液とした溶液の $\mathrm{H}_{2} \mathrm{SO}_{4}$ 濃度 $(150 \mathrm{~g} / l)$ を各試料溶液の $\mathrm{H}_{2} \mathrm{SO}_{4}$ 濃度から差し引いた値に対 して示した。いずれの硫酸塩もその濃度とともに表面張力を直線 的に上昇させるが, 表面張力の值はカチオンの種類によらずほぼ 同程度であることがわかる。 $\mathrm{MgSO}_{4}$ を含む酸性 $\mathrm{ZnSO}_{4}$ 溶液の表 面張力を $\mathrm{ZnSO}_{4}$ と $\mathrm{MgSO}_{4}$ のモル濃度の和に対して示したが, そ れぞれの単一の硫酸塩を含む溶液と同様な表面張力の硫酸塩濃度 依存性を示した。また，2 価金属硫酸塩による表面張力の増加は $\mathrm{H}_{2} \mathrm{SO}_{4}$ による増加よりも大きい。

$3 \cdot 1 \cdot 2$ 温度に伴う変化 各溶液の表面張力は図 8 の $\mathrm{H}_{2} \mathrm{SO}_{4}$ 濃度 $150 \mathrm{~g} / l$ の一連の $\mathrm{ZnSO}_{4}$ 溶液の例にみられるように温 度の上昇とともにほぼ直線的に低下した。本図では比較のために 純水および $\mathrm{ZnSO}_{4}$ を含まない硫酸溶液の表面張力の温度変化を

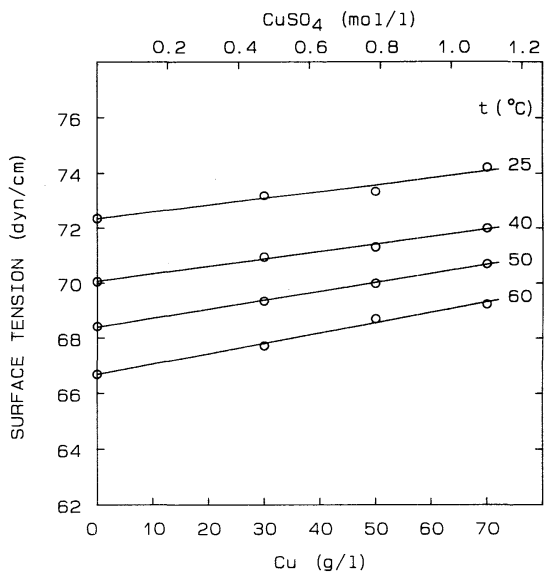

Fig. 4 Variation of surface tension with concentration of $\mathrm{CuSO}_{4}$. $\mathrm{H}_{2} \mathrm{SO}_{4} 50 \mathrm{~g} / l$

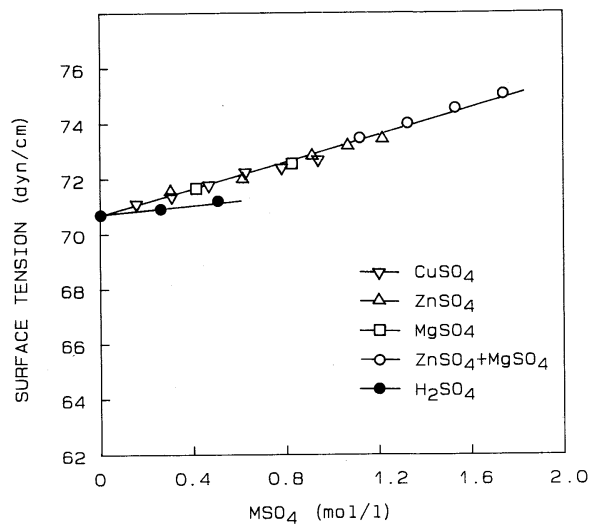

Fig. 7 Variation of surface tension with concentration of various sulfates. $\mathrm{H}_{2} \mathrm{SO}_{4} 150 \mathrm{~g} / l ; 40^{\circ} \mathrm{C}$

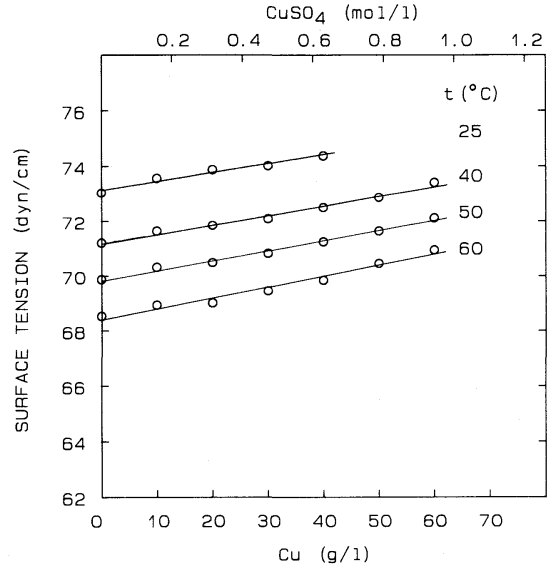

Fig. 5 Variation of surface tension with concentration of $\mathrm{CuSO}_{4}$. $\mathrm{H}_{2} \mathrm{SO}_{4} 200 \mathrm{~g} / l$

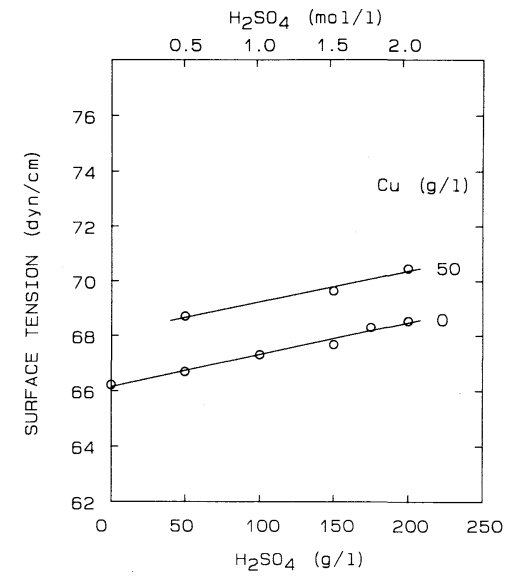

Fig. 6 Variation of surface tension with concentration of $\mathrm{H}_{2} \mathrm{SO}_{4}$ at $60^{\circ} \mathrm{C}$.

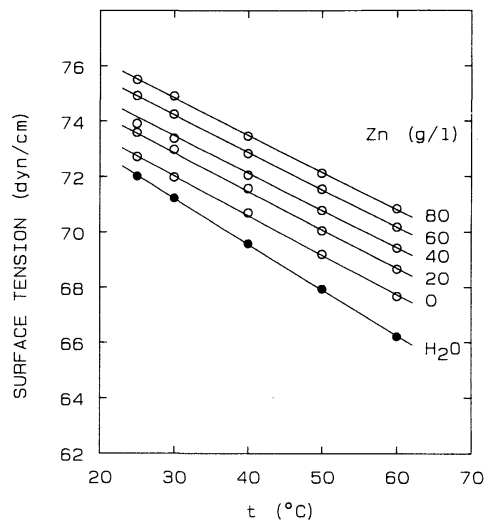

Fig. 8 Dependence of surface tension on temperature. 
併記した。 $\mathrm{H}_{2} \mathrm{SO}_{4}$ および $\mathrm{ZnSO}_{4}$ を含む場合は,純水に比べ表面張 力が大きく, 温度に伴う変化は小さくなっている。また, 表面張 力の温度に伴う変化の度合は $\mathrm{ZnSO}_{4}$ 濃度の上昇に伴ってやや小 さくなる傾向がある。酸性 $\mathrm{CuSO}_{4}$ 溶液の表面張力の温度に伴う変 化は図 8 に示した酸性 $\mathrm{ZnSO}_{4}$ 溶液の場合と同様である。

単一の電解質の水溶液では表面張力は溶質濃度とともに上昇し, 無機塩の浱度に伴う表面張力の変化は界面活性物質による変化に 比較すると非常に小さいことが知られている。無機塩の水溶液で は溶液表面への溶質の負吸着がおこると考えられており，また， アニオンが共通の塩の間では強い水和を示す溶質ほど界面不活性 度が著しいことが認められている ${ }^{7)}$ 。本研究で対象とした酸性硫 酸塩溶液においても, 単一電解質の溶液と同様に酸および硫酸塩 濃度の培加に伴って表面張力の小さな上昇がみられ，2 価金属硫 酸塩が溶液の表面張力に及ぼす影響においてもカチオンの相違に よる顕著な差が現れなかった。これは密度の測定結果を用いて計 算した硫酸塩の水和数がここで取り上げた硫酸塩に対してはほぼ 同程度であるという推定 ${ }^{8)}$ と合致している。

$3 \cdot 1 \cdot 3$ 表面張力を表す実験式 これまでに示した溶液組 成, 温度に伴う表面張力の変化を考虑し, 酸性硫酸塩溶液の表面 張力を硫酸および硫酸塩濃度, 温度の関数として表す実験式を導 出した。

溶液中の 2 価金属イオンの濃度 $[\mathrm{M}](\mathrm{mol} / l)$ を各金属イオンの 濃度 $(\mathrm{mol} / l)$ の和,

$$
[\mathrm{M}](\mathrm{mol} / \mathrm{l})=[\mathrm{Zn}]+[\mathrm{Mg}]+[\mathrm{Cu}]+[\mathrm{Ni}]
$$

で表した。さらに, 本測定の範囲では, 表面張力は硫酸および硫 酸塩濃度の上昇とともに直線的に上昇し, 温度の上昇に伴いほぼ 直線的に低下すると見られることから, 表面張力 $\gamma(\mathrm{dyn} / \mathrm{cm})$ を

$$
\gamma=K_{0}+K_{1} t+K_{2}\left(\left[\mathrm{H}_{2} \mathrm{SO}_{4}\right]+[\mathrm{M}]\right) t+K_{3}\left[\mathrm{H}_{2} \mathrm{SO}_{4}\right]
$$

$$
+K_{4}[\mathrm{M}]
$$

と表すことができると考えられる。亜鉛, 銅の電解製鍊電解夜の 組成範囲の溶液の表面張力を表す実験式として, $25 \sim 60^{\circ} \mathrm{C}$ の温度， $t\left({ }^{\circ} \mathrm{C}\right)$, において

$$
\begin{aligned}
\gamma(\mathrm{dyn} / \mathrm{cm})=75.30 & -0.153 t+0.007\left(\left[\mathrm{H}_{2} \mathrm{SO}_{4}\right]+[\mathrm{M}]\right) t \\
& +0.67\left[\mathrm{H}_{2} \mathrm{SO}_{4}\right]+2.12[\mathrm{M}] \quad \cdots \cdots(3)
\end{aligned}
$$

が得られた。(3)式によって本実験の全測定値を表すと, 標準偏差 は $0.17 \mathrm{dyn} / \mathrm{cm}$ となった。溶液中の各成分の表面張力への寄与に 関してさらに考察を進めるために必要な溶液中のイオン解離に関 するデータが不十分であり, 本研究では実験式を導出するに留ま った。

\section{3 ・2 ゼラチンを含む酸性硫酸塩溶液の表面張力}

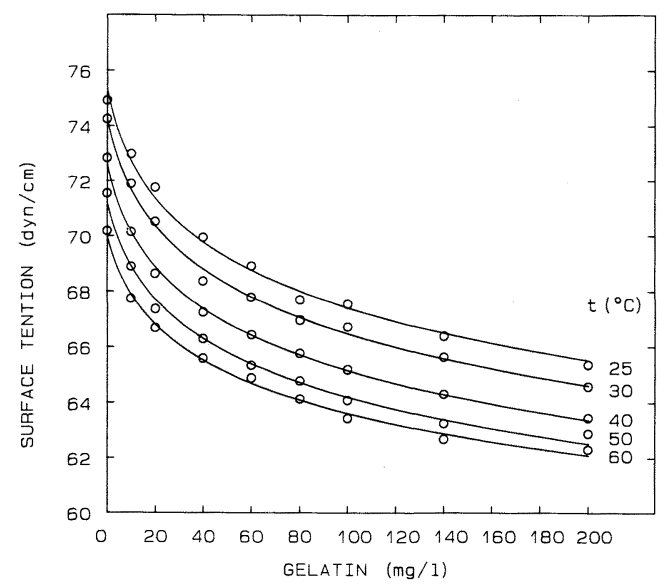

Fig. 9 Variation of surface tension with concentration of gelatin. $\mathrm{H}_{2} \mathrm{SO}_{4} 150 \mathrm{~g} / l ; \mathrm{Zn} 60 \mathrm{~g} / l$

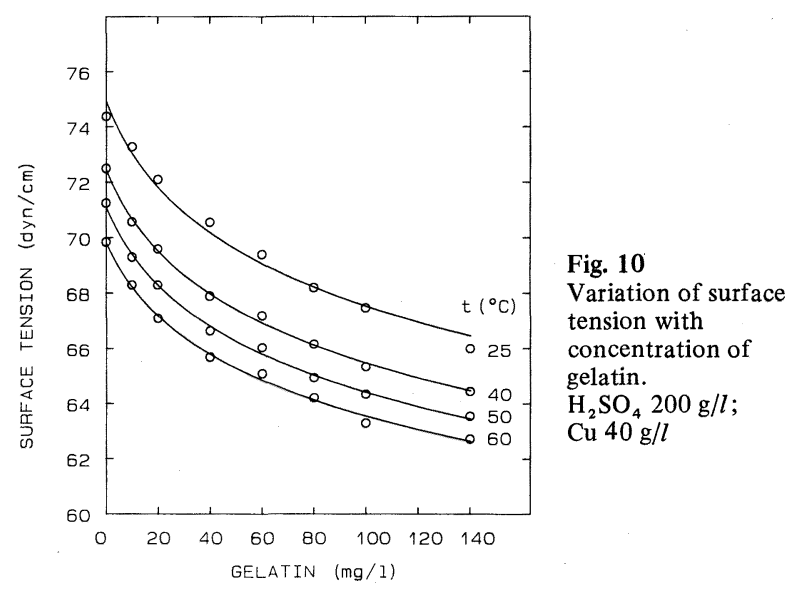

本実験では, 精製された膠であるゼラチンを $200 \mathrm{mg} / l$ までの濃 度範囲で添加し, 実操業の電解液組成, 温度に扔ける酸性硫酸塩 溶液の表面張力の変化を測定した。ゼラチンの添加により, 表面 張力の降下およびゼラチン添加後の時間の経過に伴う表面張力の 上昇といら 2 つの現象が観察された。

図9,10はゼラチンを含む溶液の調製直後に測定した脱泡間隔 $100 \mathrm{sec}$ における表面張力の值を示している。ゼラチンを添加し た酸性 $\mathrm{ZnSO}_{4}$ 溶液の表面張力とゼラチン添加量の関係を図 9 に示 した。いずれの温度でも, ゼラチンを添加した溶液は無添加の溶 液に比較して低い表面張力を示した。とくに少量のゼラチンの添 加で表面張力の降下が大きく, 添加量が $100 \mathrm{mg} / \mathrm{l}$ 以上ではゼラチ ン添加量の上昇に伴う表面張力の降下がゆるやかになった。図10 に示した酸性 $\mathrm{CuSO}_{4}$ 溶液においてもゼラチンの添加量の増加に伴

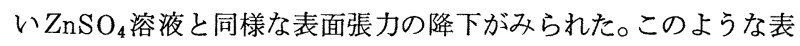
面張力の変化は界面活性剂を含む溶液でみられる現象であるが, 電解製鍊で用いられる高い酸濃度および硫酸塩濃度の溶液でもゼ ラチンの界面活性物質としての挙動が現れている。

$\mathrm{H}_{2} \mathrm{SO}_{4}$ あるいは硫酸塩濃度の $1 \mathrm{~mol} / l$ の増加に伴う表面張力 の変化が約 $2 \mathrm{dyn} / \mathrm{cm}$ 程度の小さな上昇であるのに対し, ゼラチ ンを含む溶液では $40 \mathrm{mg} / l$ 程度の低濃度の添加でも約 $5 \mathrm{dyn} / \mathrm{cm}$ の表面張力の降下がみられた。これは, ゼラチンの溶液表面への 正吸着によるものであると考えられる。

ゼラチンを含む溶液の表面張力の温度に伴う変化を図 11 に酸性 $\mathrm{ZnSO}_{4}$ 溶液の場合を例として示した。ぜラチンを含まない溶液で は, 前述のように温度の上昇に伴って表面張力がほぼ直線的に低 下寸るのに対し，ゼラチンを含む溶液では， $40^{\circ} \mathrm{C}$ 程度までは温度

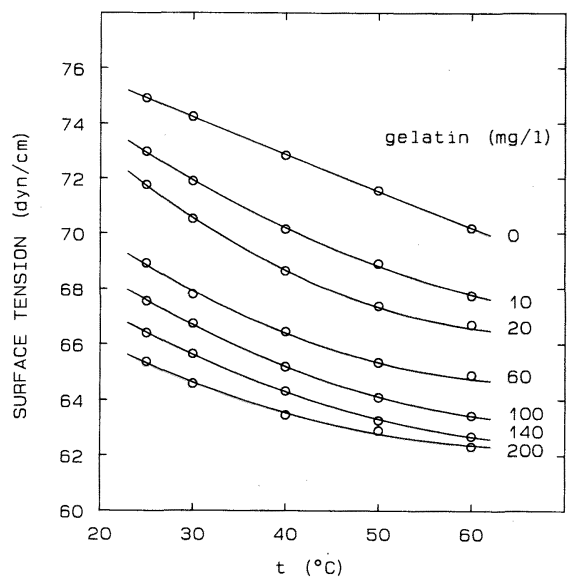

Fig. 11 Variation of surface tension with temperature. $\mathrm{H}_{2} \mathrm{SO}_{4} 150 \mathrm{~g} / l ; \mathrm{Zn} 60 \mathrm{~g} / \mathrm{l}$ 


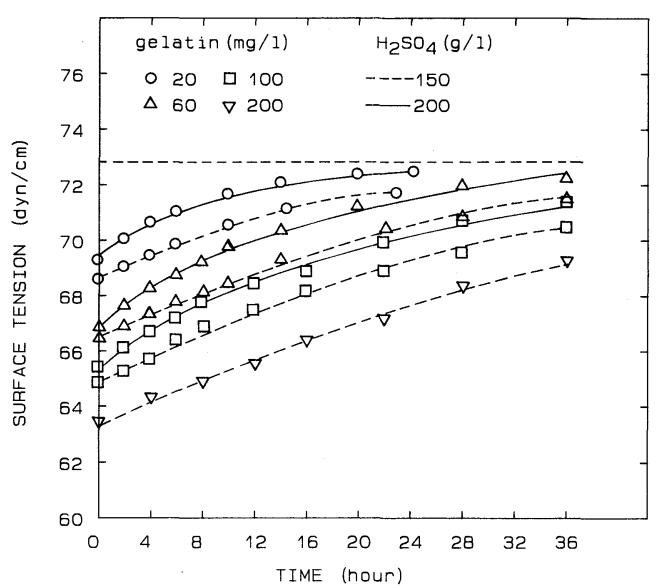

Fig. 12 Variation of surface tension with time. $\mathrm{Zn} 60 \mathrm{~g} / l ; 40^{\circ} \mathrm{C}$

に伴う表面張力の低下の度合が大きいが, さらに高い温度ではこ の変化の度合が小さくなるといら異なる温度変化がみられた。

ゼラチンを含む溶液ではゼラチン添加直後の表面張力の降下に くわえて時間の経過に伴って表面張力が次第に上昇することが観 察された。以下にゼラチンを添加した溶液の表面張力の時間に伴 う変化を銅, 亜鉛の電解液を代表する組成の溶液について述べる。 図12にゼラチンを含む酸性 $\mathrm{ZnSO}_{4}$ 溶液の表面張力の時間に伴 う変化を $\mathrm{H}_{2} \mathrm{SO}_{4}$ 濃度 150 および $200 \mathrm{~g} / l, \mathrm{Zn} 60 \mathrm{~g} / l, 40^{\circ} \mathrm{C}$ 溶液 について比較した。図中の水平な破線はゼラチン無添加の $\mathrm{H}_{2} \mathrm{SO}_{4}$ 濃度 $150 \mathrm{~g} / l$ の溶液の表面張力の值を示す。ゼラチンを含むいず れの溶液でも, 時間の経過とともに表面張力の上昇がみられた。 ゼラチン濃度 $20,60,100 \mathrm{mg} / l$ のいずれの場合も, $\mathrm{H}_{2} \mathrm{SO}_{4}$ 濃度が 高い方が $5 \sim 6$ 時間までの表面張力の上昇速度が大きく, ゼラチ ン添加による表面張力の降下が速く消失する傾向がある。表面張 力の上昇の速さは, 時間の経過とともに次第に小さくなり, ゼラ チンの無添加の溶液の表面張力の值へ漸近するという変化を示す。 また, いずれの硫酸濃度でも, 表面張力の上昇はゼラチンの初期 濃度によらずほぼ同様な速さで進行し, ゼラチン無添加の溶液の 值に到達するまでの時間はゼラチンの添加量が多いほど長くなる といら傾向がみられる。

銅の電解精製の操業条件に近い $\mathrm{H}_{2} \mathrm{SO}_{4} 200 \mathrm{~g} / l, \mathrm{Cu} 40 \mathrm{~g} / l, 60$ C における表面張力の経時変化を図13に示した。図12に示した例 に比べ, ゼラチン添加後の時間に伴う表面張力の上昇が速く, ぜ ラチン添加量が $100 \mathrm{mg} / l$ と高い場合でも, 7 時間程度でゼラチン 無添加の溶液とほぼ等しい表面張力を示し, ゼラチン添加による 表面張力の降下がほぼ消失している。

$\mathrm{H}_{2} \mathrm{SO}_{4} 200 \mathrm{~g} / l, \mathrm{Cu} 40 \mathrm{~g} / l$, ゼラチン添加量 $60 \mathrm{mg} / l$ の溶液の 40 および $60^{\circ} \mathrm{C}$ における表面張力の経時変化を図 14 に比較した。 温度の上昇が表面張力の時間に伴う上昇を大きく促進することが

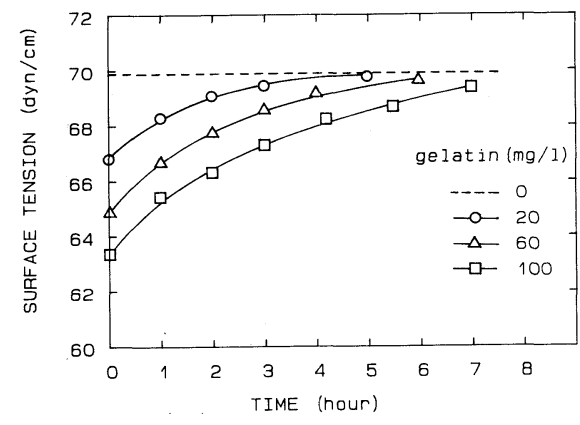

Fig. 13 Variation of surface tension with time. $\mathrm{H}_{2} \mathrm{SO}_{4} 200 \mathrm{~g} / l ; \mathrm{Cu} 40 \mathrm{~g} / l ; 60^{\circ} \mathrm{C}$

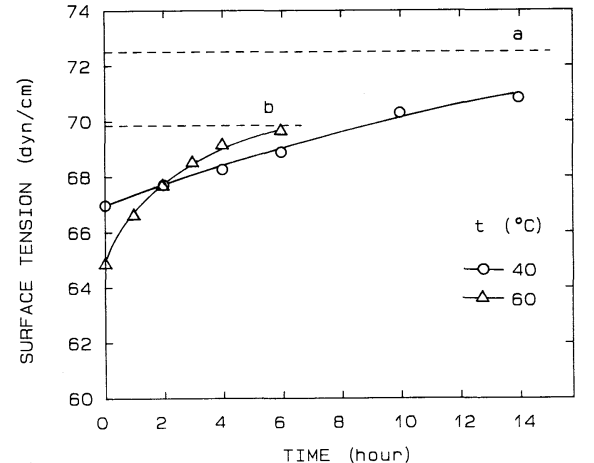

Fig. 14 Variation of surface tension with time. gelatin $60 \mathrm{mg} / l ; \mathrm{H}_{2} \mathrm{SO}_{4} 200 \mathrm{~g} / l ; \mathrm{Cu} 40 \mathrm{~g} / l$ -..-: values for solution without gelatin a: $40^{\circ} \mathrm{C} ;$ b: $60^{\circ} \mathrm{C}$

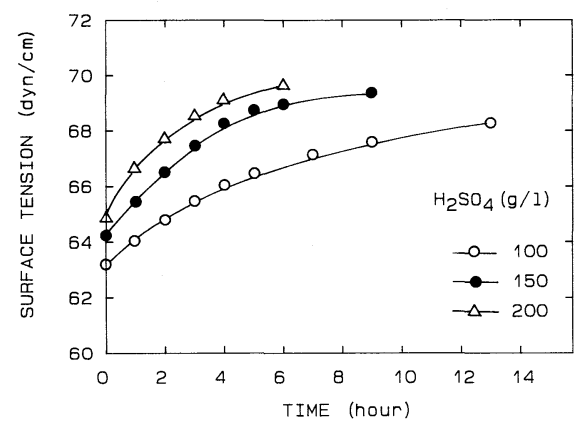

Fig. 15 Variation of surface tension with time. gelatin $60 \mathrm{mg} / \mathrm{l} ; \mathrm{Cu} 40 \mathrm{~g} / l ; 60^{\circ} \mathrm{C}$

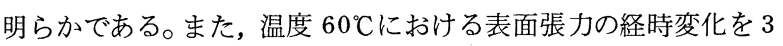
つの異なる $\mathrm{H}_{2} \mathrm{SO}_{4}$ 濃度に対して図15に示した。 $\mathrm{H}_{2} \mathrm{SO}_{4}$ 濃度が高 いほど表面張力の上昇の速さが大きくなることが明らかである。 本実験で試料溶液に添加したゼラチンは精製した膠であり，コ ラーダンを水とともに加熱して得られる誘導高分子タンパク質で あるが，これまでに報告されている分子量の值も広い範囲にわた り，原料のコラーゲンによってかなり異なった構成をとるものと 考えられる。ゼラチンは低い温度の酸溶液中では不完全加水分解 をおこし，この過程でタンパク質の特性を有する分子量の小さい 生成物へと次第に変化し，アミノ酸の比較的簡単な結合からなる ポリペプチドを経て最終的にはアミノ酸へと変化していく ${ }^{9)} 。$

本実験では溶液へ添加したゼラチンの濃度も低く, 変成の生成 物を直接追跡することはできなかった。ゼラチンの微量添加によ る表面張力の降下は高分子タンパク質であるゼラチンの溶液表面 への正吸着によるものであり, ゼラチン添加後の時間の経過に伴 う表面張力の上昇はゼラチンの不完全加水分解の逐次進行に伴う ゼラチン濃度の低下および生成物の分子量の減少によるものと考 えられる。溶液 $\mathrm{H}_{2} \mathrm{SO}_{4}$ 濃度抢よび温度の上昇にしたがってゼラチ ン添加の効果の消失が速くなることもゼラチンの不完全加水分解 の進行を示唆している。

表面張力のゼラチン濃度に伴う変化を表す式の導出を試みた結 果, 脂肪酸あるいはアルコールの $1 \mathrm{~mol} / l$ までの濃度の水溶液に 対して提唱された Szyszkowski の式 ${ }^{10)}$ と同じ形の式

$$
\gamma(\mathrm{dyn} / \mathrm{cm})=\gamma_{0}-K \cdot \log (1+\lambda C)
$$

を実験式として採用した。ここでは $K$ および $\lambda$ は定数，Cはゼラ チンの濃度 $(\mathrm{mg} / l)$ である。例えば, 図 9 に示した $\mathrm{H}_{2} \mathrm{SO}_{4} 150$ $\mathrm{g} / l, \mathrm{Zn} 60 \mathrm{~g} / l$ の溶液のゼラチン添加直後の溶液の表面張力は 40 ${ }^{\circ} \mathrm{C}$ において

$$
\lambda(\mathrm{dyn} / \mathrm{cm})=72.66-2.704 \log (1+0.15 C)
$$

と表すことができた。図 9,10 中の実線はこの形の式で計算した 


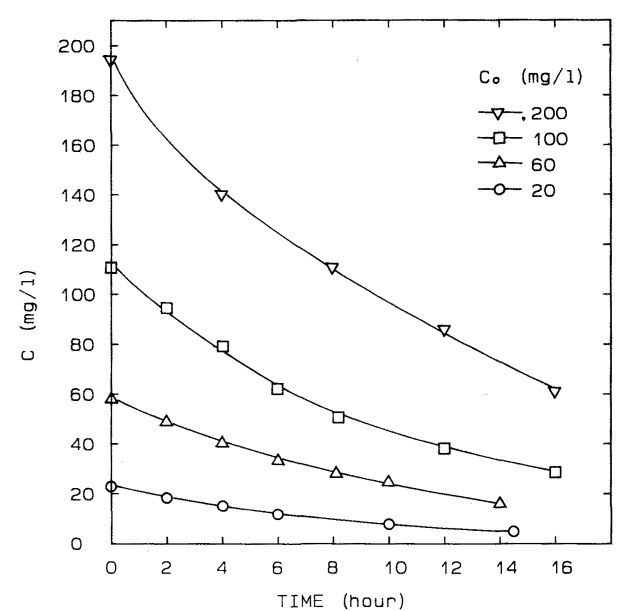

Fig. 16 Relationship between gelatin concentration, $C$, estimated from the observed surface tension by equation (5), and time. $\mathrm{H}_{2} \mathrm{SO}_{4} 150 \mathrm{~g} / l ; \mathrm{Zn} 60 \mathrm{~g} / l ; 40^{\circ} \mathrm{C}$

值であり，実測値とほぼ合致している。

本実験で対象とした $200 \mathrm{mg} /$ l以下の低いゼラチン濃度ではゼラ チンの加水分解生成物が溶液の表面張力に及ぼす影響は非常に小 さく, 溶液の表面張力の降下は溶液中に溶解しているゼラチンの 濃度によって決まるものと仮定し，ゼラチンを含む溶液の各時間 経過後の表面張力の值から(4)式によって溶液中に溶解しているゼ ラチン濃度を推定した。ここで計算されたゼラチン濃度は, 各時 間における溶液と等しい表面張力を持つ溶液を新たに調製するた めに要するゼラチンの濃度に相当する換算濃度である。酸性

$\mathrm{ZnSO}_{4}$ 溶液の $40^{\circ} \mathrm{C}$ における例を図16に示した。図からも明らか なように溶液中のゼラチンの換算濃度は時間の経過とともに低下 し, ゼラチンの初期濃度が高いほど濃度の低下が速くなっている。 図 9 に示した表面張力の変化により, $200 \mathrm{mg} / l$ までのゼラチンの 濃度簛囲を表面張力の降下が大きいゼラチンの低濃度領域, 表面 張力のゼラチン添加量に伴う変化が小さい高濃度域および 60〜 $100 \mathrm{mg} / l$ の中間領域の 3 つ範囲に分けて考えることができる。 ゼラチン濃度が低い領域ではゼラチン濃度の上昇とともに溶液表 面に正吸着するゼラチン量の増加およびこれに伴う表面張力の降 下が進み, $60 \sim 100 \mathrm{mg} / \mathrm{l}$ における溶液表面へのゼラチンの吸着状 態の遷移を経てそれ以上の漂度ではゼラチンの吸着が飽和状態に 漸近するためにゼラチン添加量の増加に伴う表面張力の降下が緩 やかになると推定される。したがって, 表面張力の值から計算され るゼラチンの換算濃度は $60 \sim 100 \mathrm{mg} /$ /の範囲では誤差が大きくな る可能性があり, それ以上で婊面張力の変化に対する換算濃度 の変化がゼラチンの低濃度域よりも大きく現れるという傾向がある。 また, 加水分解過程における各種生成物が表面張力に及ぼす影響 についてもさらに詳細な測定が必要であると考えられる。しかし， 電解液に添加したゼラチンの活性度を追跡する際に溶液の表面張 力, ゼラチンの換算踳度が有効な手段となり得ると考えられる。

チオ尿素はゼラチンとともに銅電解液への代表的な添加剤とし て用いられている。チオ尿素を $140 \mathrm{mg} / l$ までの濃度範囲で添加し て溶液の表面張力を測定した。チオ尿素の添加は本実験で対象と した酸性硫酸塩溶液では表面張力に影響を及ぼさないことが明ら かになった。また，ゼラチンを含む溶液にチオ尿素を加えても， ゼラチンの添加による表面張力の降下およびその経時変化に影響 を及ぼさないことがわかった。

銅電解液中の膠の濃度の推定法としては, Andersen $5^{11}$ 斺よび Krezewska ${ }^{12)}$ の電気化学的方法がある。銅のマイクロカソー ドを用いた定電流電解では, カソード電位が膠の添加量と共に変
化することを利用し，カソード電位一膠添加量の検量線を用いて 濃度の決定を試みた方法がある。この方法では, マイクロカソー ド表面の状態や共存アニオンの影響を強く受けるという困難さを 伴う。また, この電気化学的方法では溶液中のチ才尿素を予め分 解する必要がある。

以上のように, 溶液中のゼラチンの変成が溶液の表面張力の変 化と対応していると考えられることから, ゼラチンを含む電解液 の表面張力を測定し， ゼラチン添加の有効性を追跡する手段とし て利用できるものと考えられる。

\section{4. 結言}

亜鉛の電解採取, 銅の電解精製および採取で用いられる電解液 の組成を中心として酸性 $\mathrm{ZnSO}_{4}$ および $\mathrm{CuSO}_{4}$ 溶液の表顓張力を 測定した。実操業の電解液に含まれている代表的な共存硫酸塩で ある $\mathrm{MgSO}_{4}$ および $\mathrm{Ni} \mathrm{SO}_{4}$ を含む溶液についても測定を行なった。 また, 電解液への代表的な有機添加剤であるゼラチンが溶液の表 面張力に及ぼす影響, ゼラチンを含む溶液の表面張力の時間変化 を調べた。

本実験の測定範囲では酸性硫酸塩溶液の表面張力は硫酸および 硫酸塩濃度, 温度とともにほぼ直線的に変化し,

$$
\begin{aligned}
\gamma=75.30-0.153 \mathrm{t} & -0.007\left(\left[\mathrm{H}_{2} \mathrm{SO}_{4}\right]+[\mathrm{M}]\right) \mathrm{t} \\
+ & 0.67\left[\mathrm{H}_{2} \mathrm{SO}_{4}\right]+2.12[\mathrm{M}]
\end{aligned}
$$

で表すことができた。ここで $[\mathrm{M}](\mathrm{mol} / l)$ は溶液中の 2 洒金属イ オンの濃度であり, 各金属イオンの濃度 $(\mathrm{mol} / l)$ の和,

$[\mathrm{M}]=[\mathrm{Zn}]+[\mathrm{Mg}]+[\mathrm{Cu}]+[\mathrm{Ni}]$

として表される。

ゼラチンは $200 \mathrm{mg} / \mathrm{l}$ 以下の少量の添加で電解液のような高濃度 の酸性硫酸溶液においても表面張力を著しく降下させる。ゼラチ ン添加に伴う溶液の表面張力の降下の度合は添加量の増加ととも に小さくなる。また，ゼラチンを含む溶液の表面張力はゼラチン 添加後の時間の経過とともに上昇した。表面張力の上昇は溶液の 硫酸濃度が高く, 温度が高いほど速い。これは溶液中のゼラチン の不完全加水分解が逐次進行することによると考えられる。

チオ尿素は $140 \mathrm{mg} / l$ の濃度範囲では溶液の表面張力に影響を及 ぼさなかった。

ゼラチンを含む電解液の表面張力の測定を通して添加剤のゼラ チンの有効性を追跡することが可能であると考えられる。

\section{参 考 文 献}

1）梅津良昭·蘇慶泉・戸沢一光：日本鉱業会誌, 104 [1209], (1988), 829

2）梅津良昭·蘇鹿泉 ·戸沢一光：資源・素材学会誌，105[No.9], 693 699, (1989)

3) K. Tozawa, Y. Umetsu and Qing-quan Su: Metall. Trans. 投稿中

4) Y.Umetsu, Qing-Quan Su and K. Tozawa: Hydrometa11 urgy 投稿中

5) D. R. Fosnacht and T. J. O'Keef: Metall. Trans. B, $14 \mathrm{~B}(1983), 645$

6) W. D. Harkins: "Physical Methods of Organic Chemistry, Part I", (1949), 355, Interscience Publication, New York

7) 押田勇雄・都筑卓司：“液体·非晶質の物性工学”牧島象二編, (1968)，141，オーム社

8）蘇慶泉・梅津良昭·戸沢一光: 東北大学選研彙報, 44, 1 (1988), 112

9) 小竹無二雄：“大有機化学 21 天然高分子化合物 III” , (1960), 7 , 朝倉書店

10）中垣正幸：“表面状態とコロイド状態”，(1968)，101，東京化 学同人

11) T.N. Andersen, R. D. Budd and R.W. Strachan : Metyall. Trans. B. 7 B (1976), 333-38

12) S. Krezewska, L. Pajdowski, H. Podssiadly and J. Podsiadly : Metall. Trans. B, 15B (1984), 451-459 